\title{
NEUROSYPHILIS (GENERAL PARESIS)* REPORT OF A CASE OF FAILURE OF PENICILLIN TREATMENT
}

\author{
BY \\ D. A. BIRKETT \\ Venereal Diseases Department, St. Bartholomew's Hospital
}

Penicillin has now been used in the treatment of syphilis for over 15 years. There has been an increasing tendency during this time to rely on penicillin alone to the exclusion of other methods of treatment. A recent survey of findings in a group of 1,086 patients with neurosyphilis in the United States of America by Hahn and twelve others (1959) showed no significant difference in the results of treatment by penicillin alone and by penicillin plus fever therapy, provided that the course of penicillin consisted of more than 6 million units. Nicol (1956) pointed out that Continental practice differed from American in that fever therapy, in addition to penicillin, was the treatment of choice. It is interesting, in the light of these reports, to give an account of a case of neurosyphilis which failed to respond to three separate courses of penicillin therapy.

\section{Case Report}

A 58-year-old man, employed in the Foreign Exchange Department of a large Bank, first presented to the Surgical Out-Patient Department in November, 1954 with an episode of acute retention of urine. The prostate gland was not enlarged and, during the course of investigations into the reason for the retention, positive blood Wassermann and Kahn reactions were found. A chest $x$ ray was normal. The patient gave a history of syphilis in 1918, treated by injections at a hospital for 2 years. There had been no further symptoms of syphilis since then. Examination of the nervous system showed no abnormal physical signs but it was felt by the surgeons that the retention could be due to a "neurogenic" bladder. The patient was referred to the Venereal Disease Department.

A full assessment of mental status showed some slight loss of memory. Examination of the cerebrospinal fluid at the time showed 11 lymphocytes and 1 polymorphonuclear leucocyte per c. mm.; protein $50 \mathrm{mg}$./ $100 \mathrm{ml}$. with a raised globulin; positive Wassermann reaction; Lange curve 5555432100.

* Received for publication May 26, 1960.
It was considered that the patient had early general paresis, and he was treated with procaine penicillin $(9,000,000$ units) followed by bismuth oxychloride (3.6 g.). In June, 1955, the cerebrospinal fluid showed 3 lymphocytes per c. $\mathrm{mm}$.; protein $60 \mathrm{mg} . / 100 \mathrm{ml}$.; positive Wassermann reaction; Lange curve 3354321000 .

In November, 1956, the cerebrospinal fluid showed 2 lymphocytes per c. $\mathrm{mm}$.; protein $60 \mathrm{mg} . / 100 \mathrm{ml}$. with a raised globulin; positive Wassermann reaction; Lange curve 3432100000 . In view of the persistently raised protein a further $10,000,000$ units procaine penicillin was given.

In March, 1958, the patient remained symptomless and the cerebrospinal fluid showed 32 lymphocytes per c.mm.; protein $55 \mathrm{mg}$. $100 \mathrm{ml}$.; Lange curve 3433210000 . Because of the raised cell count a third course of $12,000,000$ units penicillin was given followed by $3 \mathrm{~g}$. bismuth. After this course, the cerebrospinal fluid showed 4 lymphocytes per c.mm.; protein $45 \mathrm{mg}$./ per cent.; Lange curve 2433210000 . The blood Wassermann reaction had remained positive all this time.

The patient had three more attacks of acute urinary retention during the next 2 years, after the last of which a transurethral resection of the prostate for median lobe enlargement was carried out. Since then there have been no further urinary complaints.

Early in 1959, the patient began to show behaviour peculiarities, with increasingly frequent bouts of morose and angry behaviour, including the use of obscene and abusive language to his wife, although at no time did he become violent. He also became increasingly argumentative with strangers. Amnesia for these episodes was complete.

In August, 1959, a psychiatric interview in the patient's home showed gross impairment of memory, impaired appreciation of time, complete lack of insight into his behaviour abnormalities and fatuous and irrelevant conversation.

The patient was then admitted to hospital. The cerebrospinal fluid showed 14 lymphocytes per c.mm.; protein $56 \mathrm{mg} . / 100 \mathrm{ml}$; Lange curve 0111000000 . Physical examination was normal.

A consultant psychiatrist diagnosed general paresis, and the patient was transferred for psychiatric treatment 
and has been given a course of fever therapy at the Mott Clinic, Horton Hospital, Epsom.

\section{Discussion}

Among the points made by Hahn and others (1959) were the following:

(1) After treatment with at least 6 million units of penicillin, re-treatment did not benefit those patients who had shown no clinical improvement.

(2) General paresis was not observed to develop after penicillin treatment of asymptomatic neurosyphilis.

(3) Re-treatment was indicated if the initial course of penicillin was less than 6 million units, if the patient showed temporary clinical improvement followed by regression, or if the cerebrospinal fluid cell count was more than 5 per c.mm. one year after treatment. Re-treatment was not indicated for absence of clinical improvement, or for persistently abnormal cerebrospinal fluid protein levels or positive Wassermann reactions following a full course of treatment.

(4) Persistent cell counts of 11 or more were not usually encountered after penicillin treatment; clinical progression did occur more frequently in patients with persistent cell counts of 5-10 than in those with counts of 4 or less.
In the case reported above the patient presented with minimal clinical evidence of neurosyphilis 5 years ago. In spite of an initial satisfactory response after each course of penicillin the cell count again became abnormally high. Five years after the original diagnosis the patient developed obvious symptoms of general paresis.

\section{Summary}

A case of general paresis is reported in which clinical and cerebrospinal fluid relapses followed three adequate courses of penicillin therapy.

I should like to thank Dr. C. S. Nicol and Dr. Linford Rees for permission to publish this case.

\section{REFERENCES}

Hahn, R. D., Webster, B., Weickhardt, G., Thomas, E., Timberlake, W., Solomon, H., Stokes, J. H., Moore, J. E., Heyman, A., Gammon, G., Gleeson, G. A., Curtis, A. C., and Cutler, J. C. (1959). A.M.A. Arch. Neurol. Psychiat., 81, 557.

Nicol, W. D. (1956). Proc. roy. Soc. Med., 49, 135.

\section{Neurosyphilis (paralysie générale)}

\section{Résumé}

L'auteur rapporte un cas de paralysie générale dans lequel trois traitements complets par la pénicilline furent suivis de rechutes corroborées par les examens cliniques et du liquide céphalo-rachidien. 